\title{
Age Differences in the Relationship between Secondhand Smoke Exposure and Risk of Metabolic Syndrome: A Meta-Analysis
}

\author{
Hui-Jian Chen $($, Gai-Ling Li, Ao Sun, Dang-Sheng Peng, Wan-Xia Zhang and You-E Yan* \\ Department of Pharmacology, Wuhan University School of Basic Medical Sciences, Wuhan 430071, China; \\ 2016203010030@whu.edu.cn (H.-J.C.); 2016203010033@whu.edu.cn (G.-L.L.); sunaonihao@foxmail.com (A.S.); \\ 2018203010028@whu.edu.cn (D.-S.P.); zhangwanxia92@163.com (W.-X.Z.) \\ * Correspondence: yanyoue@whu.edu.cn; Tel.: +86-027-68759222
}

Received: 30 December 2018; Accepted: 17 April 2019; Published: 19 April 2019

check for updates

\begin{abstract}
Secondhand smoke (SHS), a common environmental exposure factor, has become a serious public health problem. Metabolic syndrome is another worldwide clinical challenge. Our study tried to determine the age differences in the relationship between SHS and the risk of metabolic syndrome. Studies were searched in PubMed and Web of Science from 11 November to 30 November 2018. Eighteen studies were finally included based on inclusion and exclusion criteria. The relationship between SHS and the risk indicators of metabolic syndrome was analyzed. The weighted mean difference (WMD) of fasting plasma glucose (FPG), insulin, body mass index (BMI), and waist circumference (WC), and the standard mean difference (SMD) of total cholesterol, triglycerides, and low- and high-density lipoprotein-cholesterol (LDL-C, HDL-C) were calculated in a meta-analysis. SHS was positively associated with the level of insulin and WC. According to the subgroup analysis based on age difference, SHS was positively associated with FPG in the upper age group, and positively associated with LDL-C and negatively associated with HDL-C in the lower age group. BMI showed a more obvious positive correlation in the adults group than in the children and the teenagers group. In conclusion, the association of metabolic syndrome with SHS varies with age. When exposed to SHS, older people may be more susceptible to glucose metabolic disorder, but younger people may be more susceptible to lipid metabolic disorder.
\end{abstract}

Keywords: secondhand smoke; metabolic syndrome; age difference; glucose metabolism; lipid metabolism; meta-analysis

\section{Introduction}

Secondhand smoke (SHS), a common public health problem, refers to the burning tobacco products or gas exhaled by smokers. Globally, about $40 \%$ of children, $33 \%$ of adult male non-smokers, and 35\% of adult female non-smokers were exposed to SHS in 2004 [1]. Smoking by household members or colleagues may be a major pathway for SHS. This kind of exposure is passive and easily overlooked. However, SHS caused around 600,000 deaths in 2004, among which $47 \%$ were women, $26 \%$ were men, and $28 \%$ were children [1]. In fact, SHS is associated with various diseases, such as heart disease [2], asthma [3], lung cancer [4], and cardiovascular diseases [5]. Recently, the effects of SHS on endocrine and metabolism diseases have been studied. According to Kim et al.'s study, exposure to SHS may be a risk factor for diabetes management [6]. Oba et al. reported that SHS decreases the sensitivity of insulin and pancreatic $\beta$-cell function and appears to be associated with diabetic states [7].

Metabolic syndrome is one of the major public health and clinical challenges worldwide. In the United States, $4.5 \%$ of adolescents, $35 \%$ of adults, and as much as $50 \%$ of the people aged over 60 years 
suffer from metabolic syndrome [8,9]. Metabolic syndrome, according to the National Cholesterol Education Program (NCEP) criteria, is a group of three or more risk factors, which include abdominal obesity, dyslipidemia such as low levels of high-density lipoprotein cholesterol (HDL-C) and high levels of triglycerides, high blood pressure, and elevated fasting plasma glucose (FPG) [10,11]. Many factors may induce metabolic syndrome, including unhealthy eating habits, short sleep duration, and lack of exercise [12-15], but the effects of SHS on metabolic syndrome have not been fully studied. In our meta-analysis, we analyze the relationship of SHS with some risk indicators of metabolic syndrome in young people and adults, such as fasting plasma glucose (FPG), insulin, total cholesterol, triglycerides, low-density lipoprotein cholesterol (LDL-C), HDL-C, body mass index (BMI), and waist circumference (WC). Moreover, a subgroup analysis based on age difference is conducted. SHS, as a common environmental factor, may be a potential factor that induces metabolic syndrome, but the harm caused by SHS is easily overlooked. Our study focuses on these two important public health issues and tries to explore the links between SHS and metabolic syndrome and potential differences between age groups. In doing so, this contributes to gaining a deeper understanding of the passive effects of SHS. Currently, no relevant review has been published.

\section{Materials and Methods}

\subsection{Search Strategy}

Articles were identified by searches of PubMed and Web of Science, and all documents were collected from 11 November to 30 November 2018.

The following key words were used:

\#1 Environmental tobacco smoking OR passive smoking OR secondhand smoking OR household smoking;

\#2 Free fatty acids OR total cholesterol OR triglycerides OR HDL-C OR LDL-C OR glucose OR insulin OR blood biochemistry OR body weight OR BMI OR waist circumference OR obesity OR overweight;

\#1 AND \#2.

\subsection{Study Selection}

Studies were imported into EndNote X7 (Thompson Reuters, San Francisco, CA, USA), and duplicate records were removed. All articles were screened independently through titles and abstracts by two reviewers (H.J. Chen and G.L. Li), and relevant full-texts were obtained.

Data were extracted from the appropriate studies that met the inclusion criteria listed as follows: (1) human studies; (2) the methods and objectives of each study are similar; (3) the results of the survey include at least one set of data; (4) the measurement data provides the means, standard deviation, and sample size; and (5) the study type is a cohort study or cross-sectional study.

The exclusion criteria included (1) repeating studies; (2) studies are defined as low quality in a quality assessment; (3) absence of some key information; (4) the data of the investigation and study are not completed through a document delivery service and full text cannot be obtained by emailing the authors; (5) the statistical method used is incorrect and cannot be modified, and the measurement data do not provide means \pm standard deviation and sample size; and (6) studies were not based on humans.

\subsection{Data Extraction}

The main extracted information included the name of the first author, the publication year, the type of study, the sample size, the study period; the methods of SHS assessment; the average age of participants; the levels of FPG, insulin, total cholesterol, triglycerides, LDL-C, and HDL-C; BMI, and WC. The data had to be converted into the same units if the units were not consistent between studies. 
For example, the units for WC could be transformed from $\mathrm{cm}$ into $\mathrm{mm}$. Some articles with more than one group of age-specific data were included in the subgroup analysis of age difference.

\subsection{Quality Assessment}

The quality of each study was independently evaluated by two authors (H.J. Chen and G.L. Li), and discrepancies were resolved by discussing with the third author (A. Sun). The quality of each cross-sectional study was evaluated by the Agency for Healthcare Research and Quality (AHRQ): low quality $=0-3$; moderate quality $=4-7$; high quality $=8-11[16]$. The quality of each cohort study was assessed by the Newcastle-Ottawa Scale (NOS) assessment, and scores ranged from 0 (lowest) to 9 (highest), and a study earning a score of seven or more was considered to be of high quality [17].

\subsection{Statistical Analysis}

Stata12.0 software (Stata Corporation, College Station, TX, USA) was used for meta-analysis. Continuous variables were presented as the weighted mean difference (WMD) with $95 \%$ confidence interval (CI). If the data could not be converted into the same units, the variables were switched to the standard mean difference (SMD) with 95\% CI. When the diamond fell to the left or right of the invalid vertical line, it was considered indicative of statistical significance. No statistical difference referred to the diamond crossing with invalid vertical line.

The Q statistic ( $p<0.10$ indicating significant heterogeneity) and the $\mathrm{I}^{2}$ statistic $\left(\mathrm{I}^{2}>75.0 \%\right.$, $50.0-75.0 \%$, and $<50.0 \%$ indicating substantial, moderate, and low heterogeneity, respectively) were used to evaluate statistical heterogeneity [18].

Meta-analyses were conducted with fixed-effect models if no significant heterogeneity was detected by the $\mathrm{Q}$ statistic $\left(p>0.10, \mathrm{I}^{2}<50.0 \%\right)$, whereas random-effect models were applied under significant heterogeneity $\left(p<0.10, \mathrm{I}^{2}>50.0 \%\right)$. In addition, subgroup analyses were conducted to evaluate the effects of age. One-way ANOVA was used to evaluate the differences in BMI between subgroups, and $p<0.05$ indicated significant statistical difference.

\section{Results}

\subsection{Literature Search}

The initial literature retrieval identified 3813 papers from the PubMed and Web of Science databases. After initial screening based on titles and abstracts, 2386 papers that did not meet the inclusion criteria were excluded (non-human studies; reviews; studies not involving SHS; results were discontinuous variables; etc.), and 188 papers were obtained. Finally, a total of 18 studies were included in this study after carefully reading the full texts (Figure 1).

\subsection{Study Characteristics and Quality Assessment}

In this study, 18 studies were finally included, and their basic characteristics are shown in Table 1. Of the included studies, six of them were cohort studies, and the remaining 12 were cross-sectional studies. The ages of the individuals involved in these studies ranged from 1 to 74 years. Thirteen studies were of high quality, and five were of moderate quality (Table 2). 
Table 1. Characteristics of included studies.

\begin{tabular}{|c|c|c|c|c|c|c|}
\hline Study & $\begin{array}{l}\text { Study } \\
\text { Period }\end{array}$ & $\begin{array}{l}\text { Study } \\
\text { Design }\end{array}$ & $\begin{array}{c}\text { SHS } \\
\text { Assessment }\end{array}$ & $\begin{array}{l}\text { Mean Age } \\
\text { (Year) }\end{array}$ & Sample Size & Variables \\
\hline $\begin{array}{l}\text { Merianos et al. } \\
\text { (2018) [19] }\end{array}$ & 1999-2012 & CS & $\begin{array}{c}\text { Non-smoker, serum } \\
\text { cotinine }(0.05-2.99 \\
\mathrm{ng} / \mathrm{mL})\end{array}$ & $12-19$ & 11,550 & WC \\
\hline $\begin{array}{l}\text { Kim et al. (2017) } \\
\text { [20] }\end{array}$ & 2008-2011 & CS & $\begin{array}{l}\text { Self-report passive } \\
\text { smoking }\end{array}$ & 45 & 7376 & $\begin{array}{l}\text { TC, LDL-C, } \\
\text { HDL-C }\end{array}$ \\
\hline $\begin{array}{l}\text { Robinson et al. } \\
\text { (2016) [21] }\end{array}$ & 2003-2008 & $\mathrm{C}$ & $\begin{array}{c}\text { Questionnaire: } \\
\text { non-smoker, passive } \\
\text { exposure at home/work }\end{array}$ & $1 / 4 / 14$ & 3174 & BMI \\
\hline $\begin{array}{l}\text { Kelishadi et al. } \\
\text { (2016) [22] }\end{array}$ & 2009-2010 & CS & $\begin{array}{l}\text { Self-report: living with } \\
\text { smokers }\end{array}$ & $10-18$ & 5625 & $\begin{array}{c}\text { BMI, WC, FPG, } \\
\text { TC, TG, } \\
\text { LDL-C, HDL-C }\end{array}$ \\
\hline $\begin{array}{l}\text { Davis et al. } \\
\text { (2016) [23] }\end{array}$ & 2003-2006 & CS & $\begin{array}{l}\text { Non-smoker, plasma } \\
\text { cotinine } \geq 0.05 \mathrm{ng} / \mathrm{mL}\end{array}$ & $7-11$ & 222 & $\begin{array}{l}\text { BMI, WC, INS, } \\
\text { FPG }\end{array}$ \\
\hline $\begin{array}{l}\text { McConnell et al. } \\
\text { (2015) [24] }\end{array}$ & NC & $\mathrm{C}$ & $\begin{array}{l}\text { Questionnaire: living } \\
\text { with smokers, quantity } \\
\text { of smokers in the } \\
\text { household }\end{array}$ & 10 & 3318 & BMI \\
\hline $\begin{array}{l}\text { Chen et al. } \\
\text { (2015) [25] }\end{array}$ & 2004-2010 & $\mathrm{C}$ & $\begin{array}{l}\text { Questionnaire: } \\
\text { non-smoker, living } \\
\text { together indoors with } \\
\text { smokers, the number of } \\
\text { exposed years }\end{array}$ & $26-48$ & 415 & BMI, LDL-C \\
\hline $\begin{array}{l}\text { Le-Ha et al. } \\
(2013) \text { [26] }\end{array}$ & 1989-2006 & $\mathrm{C}$ & $\begin{array}{l}\text { Questionnaire: quantity } \\
\text { of cigarettes smoked } \\
\text { daily in the household }\end{array}$ & 17 & 1754 & $\begin{array}{c}\text { BMI, WC, INS, } \\
\text { FPG, TC, TG, } \\
\text { LDL-C, HDL-C }\end{array}$ \\
\hline $\begin{array}{l}\text { Yang et al. (2012) } \\
\text { [27] }\end{array}$ & NC & CS & $\begin{array}{l}\text { Non-smoker, plasma } \\
\text { cotinine } \geq 0.90 \mathrm{ng} / \mathrm{mL}\end{array}$ & 16 & 624 & $\begin{array}{l}\text { TC, TG, LDL-C, } \\
\text { HDL-C }\end{array}$ \\
\hline $\begin{array}{l}\text { Dulger et al. } \\
(2011)[28]\end{array}$ & NC & CS & $\begin{array}{l}\text { Non-smoker, living } \\
\text { with smokers for at least } \\
\text { 5-6 h during the day }\end{array}$ & $27-33$ & 40 & FPG \\
\hline $\begin{array}{l}\text { Xie et al. } \\
(2010)[29]\end{array}$ & NC & CS & $\begin{array}{l}\text { Questionnaire: number } \\
\text { of days/one week in a } \\
\text { room with smokers }\end{array}$ & 38 & 389 & $\begin{array}{l}\text { BMI, WC, FPG, } \\
\text { TC, TG, LDL-C, } \\
\text { HDL-C }\end{array}$ \\
\hline $\begin{array}{l}\text { Moss et al. } \\
(2010)[30]\end{array}$ & NC & CS & $\begin{array}{l}\text { Self-report passive } \\
\text { smoking }\end{array}$ & $30-50 / 10-12$ & 41 & $\begin{array}{l}\text { FPG, TC, TG, } \\
\text { LDL-C, HDL-C }\end{array}$ \\
\hline $\begin{array}{l}\text { Kowall et al. } \\
(2010)[31]\end{array}$ & 1999-2001 & $\mathrm{C}$ & $\begin{array}{c}\text { Questionnaire: stay } \\
\text { with smokers at } \\
\text { home/work, quantity of } \\
\text { other smokers }\end{array}$ & $55-74$ & 1223 & $\begin{array}{l}\text { BMI, WC, INS, } \\
\text { FPG }\end{array}$ \\
\hline $\begin{array}{l}\text { Nagel et al. } \\
(2009) \text { [32] }\end{array}$ & 1999-2008 & CS & $\begin{array}{l}\text { Questionnaire: living } \\
\text { with smokers, quantity } \\
\text { of cigarettes smoked } \\
\text { daily in the household }\end{array}$ & 10 & 450 & BMI \\
\hline $\begin{array}{l}\text { Makris et al. } \\
(2009) \text { [33] }\end{array}$ & NC & CS & $\begin{array}{l}\text { Non-smoker, at least } 1 \mathrm{~h} \\
\text { daily domestic and/or } \\
\text { workplace smoke } \\
\text { exposure }\end{array}$ & $50-60$ & 254 & $\begin{array}{l}\text { BMI, WC, FPG, } \\
\text { TC, TG, LDL-C, } \\
\text { HDL-C }\end{array}$ \\
\hline $\begin{array}{l}\text { Houston et al. } \\
\text { (2006) [34] }\end{array}$ & NC & $\mathrm{C}$ & $\begin{array}{l}\text { Self-report and serum } \\
\text { cotinine }(1-15 \mathrm{ng} / \mathrm{mL})\end{array}$ & $18-30$ & 4572 & INS, TG \\
\hline $\begin{array}{l}\text { Mack et al. } \\
(2003)[35]\end{array}$ & NC & CS & $\begin{array}{l}\text { Questionnaire: number } \\
\text { of smokers and hours } \\
\text { per day staying with } \\
\text { smokers }\end{array}$ & 40 & 227 & $\begin{array}{l}\text { BMI, TC, TG, } \\
\text { LDL-C, HDL-C }\end{array}$ \\
\hline $\begin{array}{l}\text { Henkin et al. } \\
\text { (1999) [36] }\end{array}$ & $\mathrm{NC}$ & CS & $\begin{array}{l}\text { Structured interview: } \\
\text { living with smokers }\end{array}$ & $40-69$ & 1481 & INS \\
\hline
\end{tabular}

SHS-Secondhand smoke; NC-Not Clear; CS-Cross-sectional Study; C-Cohort Study; BMI-Body Mass Index; WC_Waist Circumference; INS_-Insulin; FPG_Fasting Plasma Glucose; TC—Total Cholesterol; TG_-Triglycerides; LDL-C-Low Density Lipoprotein Cholesterol; HDL-C-High Density Lipoprotein Cholesterol. 
Table 2. Quality assessment of included studies.

\begin{tabular}{|c|c|c|c|c|c|c|c|c|c|c|c|c|c|c|}
\hline \multirow{2}{*}{$\begin{array}{c}\text { Cross-Sectional } \\
\text { Study }\end{array}$} & \multirow{2}{*}{ Year } & \multicolumn{4}{|c|}{ Research Elements } & \multicolumn{4}{|c|}{ Quality Control } & \multicolumn{3}{|c|}{ Data Integrity } & \multirow{2}{*}{ Scores } & \multirow{2}{*}{ Quality* } \\
\hline & & 1 & 2 & 3 & 4 & 5 & 6 & 7 & 8 & 9 & 10 & 11 & & \\
\hline Merianos & 2018 & $\star$ & $\star$ & $\star$ & $\star$ & - & $\star$ & $\star$ & $\star$ & - & $\star$ & - & 8 & High \\
\hline Kim & 2017 & $\star$ & $\star$ & $\star$ & $\star$ & $\star$ & $\star$ & $\star$ & $\star$ & - & - & - & 8 & High \\
\hline Kelishadi & 2016 & $\star$ & - & $\star$ & - & - & $\star$ & - & $\star$ & - & $\star$ & - & 5 & Moderate \\
\hline Davis & 2016 & $\star$ & $\star$ & $\star$ & - & $\star$ & $\star$ & - & $\star$ & - & - & $\star$ & 7 & Moderate \\
\hline Yang & 2012 & $\star$ & $\star$ & - & - & $\star$ & $\star$ & $\star$ & $\star$ & - & - & - & 6 & Moderate \\
\hline Dulger & 2011 & $\star$ & $\star$ & - & - & $\star$ & $\star$ & $\star$ & $\star$ & - & - & - & 6 & Moderate \\
\hline Xie & 2010 & $\star$ & $\star$ & $\star$ & - & $\star$ & $\star$ & $\star$ & $\star$ & $\star$ & $\star$ & - & 9 & High \\
\hline Moss & 2010 & $\star$ & $\star$ & - & - & $\star$ & $\star$ & $\star$ & $\star$ & $\star$ & $\star$ & - & 8 & High \\
\hline Nagel & 2009 & $\star$ & $\star$ & $\star$ & - & $\star$ & - & $\star$ & $\star$ & - & $\star$ & $\star$ & 8 & High \\
\hline Makris & 2009 & $\star$ & $\star$ & - & $\star$ & $\star$ & $\star$ & $\star$ & $\star$ & - & $\star$ & $\star$ & 9 & High \\
\hline Mack & 2003 & $\star$ & - & - & - & $\star$ & $\star$ & $\star$ & $\star$ & - & $\star$ & - & 6 & Moderate \\
\hline Henkin & 1999 & $\star$ & $\star$ & - & - & $\star$ & $\star$ & $\star$ & $\star$ & - & $\star$ & $\star$ & 8 & High \\
\hline \multirow{2}{*}{ Cohort Study } & \multirow{2}{*}{ Year } & \multicolumn{4}{|c|}{ Selection } & \multicolumn{3}{|c|}{ Comparability } & \multicolumn{4}{|c|}{ Result Evaluation } & \multirow{2}{*}{ Scores } & \multirow{2}{*}{ Quality* } \\
\hline & & I & II & III & IV & & $\mathrm{V}$ & & VI & VII & \multicolumn{2}{|c|}{ VIII } & & \\
\hline Robinson & 2016 & $\star$ & $\star$ & - & $\star$ & & $\star \star$ & & $\star$ & $\star$ & \multicolumn{2}{|l|}{$\star$} & 8 & High \\
\hline McConnell & 2015 & - & $\star$ & - & $\star$ & & $\star \star$ & & $\star$ & $\star$ & \multicolumn{2}{|l|}{$\star$} & 7 & High \\
\hline Chen & 2015 & $\star$ & $\star$ & - & $\star$ & & $\star \star$ & & $\star$ & $\star$ & \multicolumn{2}{|l|}{$\star$} & 8 & High \\
\hline Le-Ha & 2013 & $\star$ & $\star$ & $\star$ & $\star$ & & $\star \star$ & & $\star$ & $\star$ & \multicolumn{2}{|l|}{$\star$} & 9 & High \\
\hline Kowall & 2010 & $\star$ & $\star$ & - & $\star$ & & $\star \star$ & & - & $\star$ & \multicolumn{2}{|l|}{$\star$} & 7 & High \\
\hline Houston & 2006 & $\star$ & $\star$ & $\star$ & $\star$ & & $\star \star$ & & - & $\star$ & \multicolumn{2}{|l|}{$\star$} & 8 & High \\
\hline
\end{tabular}

(1) Define the source of information; (2) list inclusion and exclusion criteria for exposed and unexposed subjects; (3) list the time period for identifying patients; (4) indicate whether subjects were consecutive if not population based; (5) indicate whether subjective components of evaluators were masked by other aspects of participants; (6) describe quality assurance purposes; (7) explain any patient exclusions; (8) describe how confounding was assessed or controlled; (9) explain how missing data were handled; (10) summarize patient response rates and the completeness of the data collection; (11) provide follow-up information and percentage of incomplete data. (I) Representativeness of the exposed cohort; (II) selection of non-exposed cohort; (III) ascertainment of exposure; (IV) demonstration that the outcome of interest was not present at the start of the study; (V) comparability of cohorts on the basis of the design or analysis; (VI) assessment of outcome; (VII) was follow-up long enough for outcomes to occur; (VIII) adequacy of follow-up of cohorts. $\star$-Got one score in this item; *-The quality of cross-sectional studies was evaluated by the Agency for Healthcare Research and Quality (AHRQ), and the quality of cohort studies was evaluated by the Newcastle-Ottawa Scale (NOS) assessment.

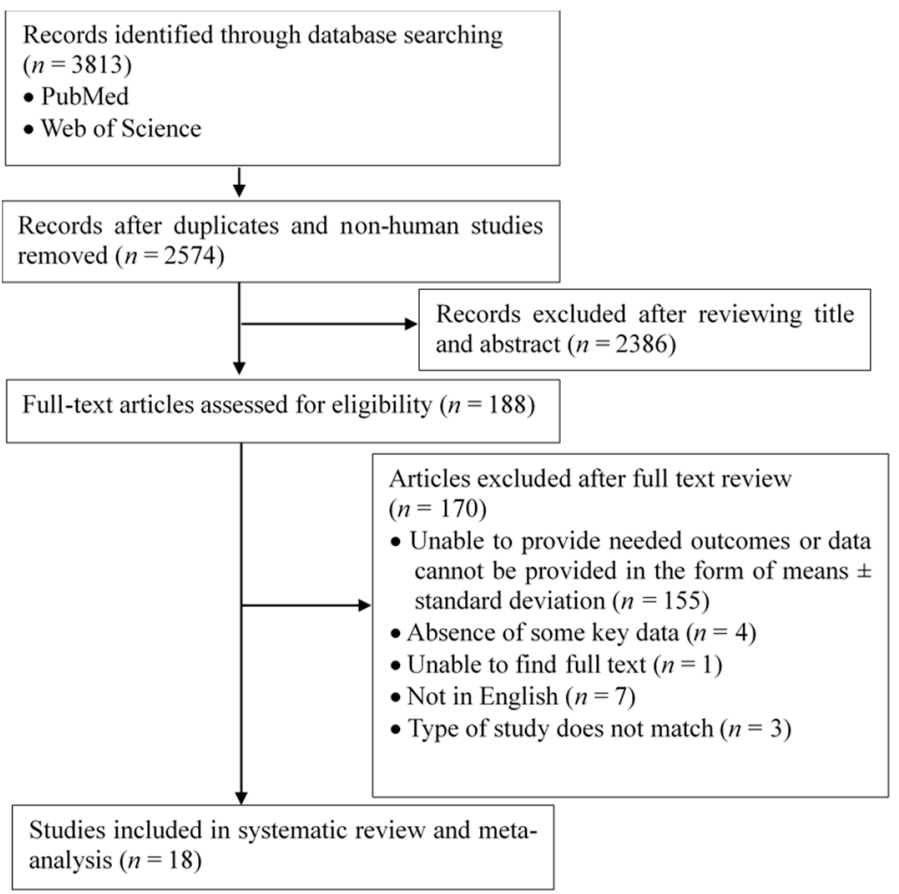

Figure 1. Flow chart of data sourcing and selection. 


\subsection{SHS and Disorder of Glucose Metabolism}

The association between SHS and glucose metabolism was analyzed. The levels of FPG and insulin were used as indexes for evaluating glucose metabolism.

Eight studies were included in the assessment of the association between SHS and FPG. The studies were divided into two subgroups: lower age group (7-18 years) and upper age group (27-74 years). It was found that SHS may be positively associated with the FPG in the upper age group $\left(\mathrm{WMD}=1.38 \mathrm{mg} / \mathrm{dL}, 95 \% \mathrm{CI}: 0.07\right.$ to $2.68 \mathrm{mg} / \mathrm{dL}, \mathrm{I}^{2}=0.0 \%$, Figure $2 \mathrm{~A}$ ), but showed no significant influence on young people. Five studies were included in the assessment of the association between SHS and insulin. It was shown that SHS may be positively associated with the level of insulin (WMD $=0.69 \mathrm{mU} / \mathrm{L}, 95 \% \mathrm{CI}: 0.35$ to $1.03 \mathrm{mg} / \mathrm{dL}, \mathrm{I}^{2}=0.0 \%$, Figure $2 \mathrm{~B}$ ).

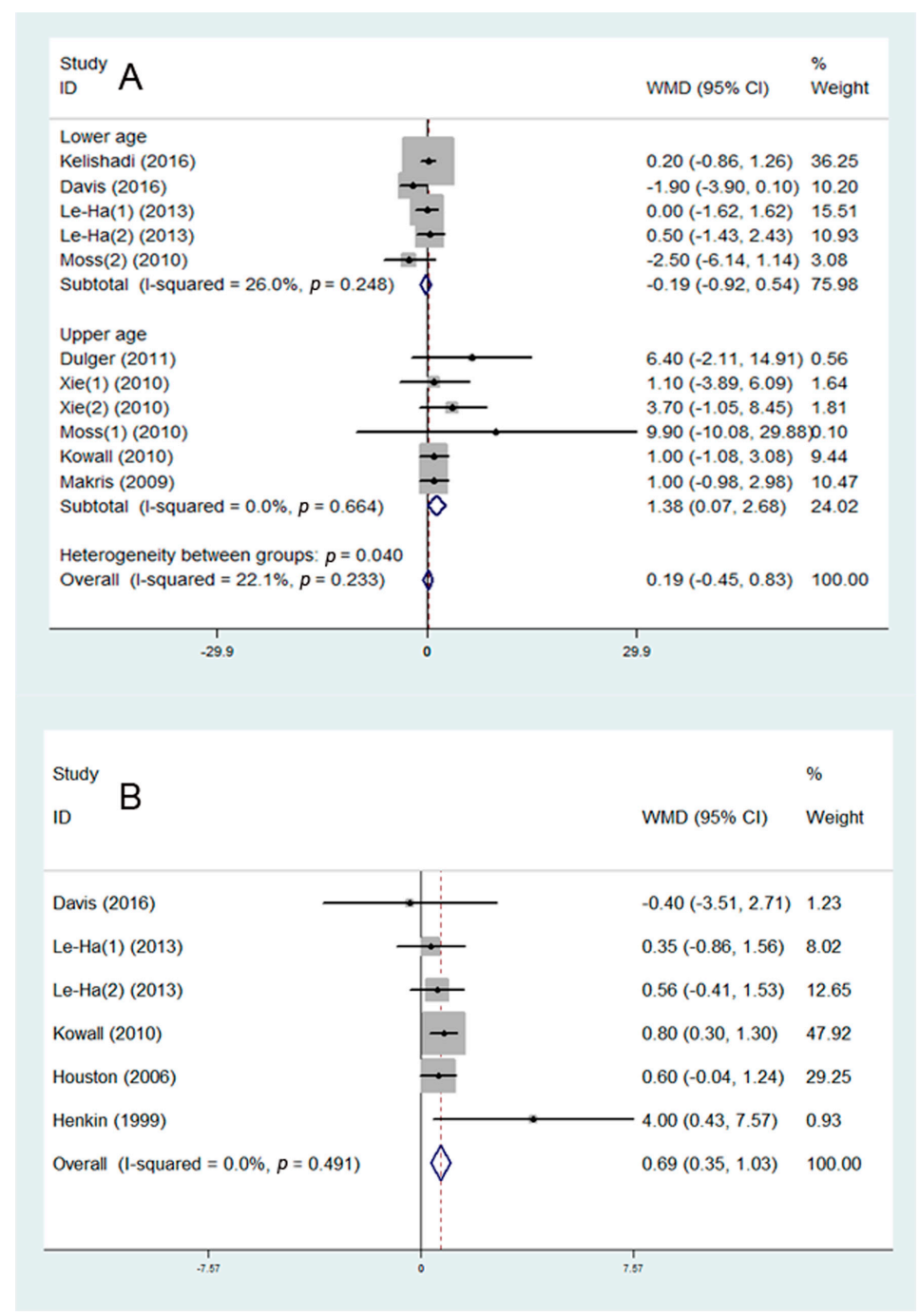

Figure 2. Meta-analysis of secondhand smoke (SHS) and risk of glucose metabolism disorder: (A) association between SHS and fasting plasma glucose (FPG); (B) association between SHS and insulin. WMD—-weighted mean difference.

\subsection{SHS and Disorder of Lipid Metabolism}

The association between SHS and lipid metabolism was analyzed. The levels of total cholesterol, triglycerides, LDL-C, and HDL-C were used as indexes for evaluating lipid metabolism. All studies were divided into two subgroups: lower age group (10-18 years) and upper age group (total cholesterol: 30-60 years; triglycerides: 18-60 years; LDL-C: 26-60 years; HDL-C: 30-60 years). 
Eight studies were included in the assessment of the association between SHS and total cholesterol. A negative association was found between SHS and total cholesterol in the upper age group (SMD $=-0.06$, 95\% CI: -0.12 to $-0.01, \mathrm{I}^{2}=0.0 \%$, Figure $3 \mathrm{~A}$ ). Nine studies were included in the assessment of the level of LDL-C. SHS may be positively associated with LDL-C level in the lower age group (SMD = 0.07, $95 \%$ CI: 0.01 to $0.13, \mathrm{I}^{2}=0.0 \%$, Figure $3 \mathrm{C}$ ), but has no effect in the upper age group. Eight studies were included in the assessment of HDL-C. A negative-related effect of SHS on HDL-C may exist in the lower age group (SMD $=-0.18,95 \% \mathrm{CI}:-0.24$ to $-0.12, \mathrm{I}^{2}=75.2 \%$, Figure $3 \mathrm{D}$ ). No significant association was found between SHS and triglycerides (Figure 3B).

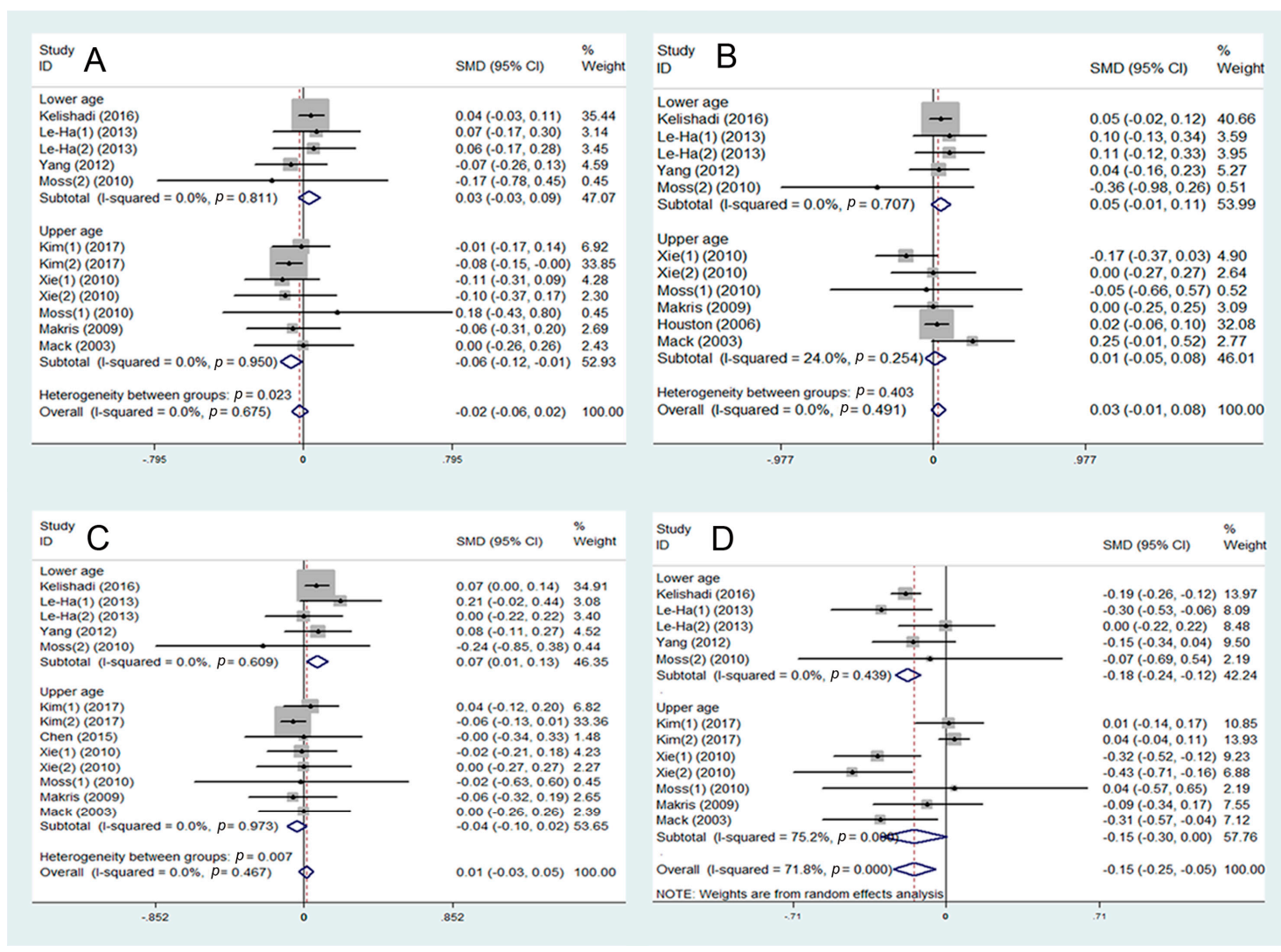

Figure 3. Meta-analysis of secondhand smoke (SHS) and risk of lipid metabolism disorder: (A) association between SHS and total cholesterol; (B) association between SHS and triglycerides; (C) association between SHS and LDL-C; (D) association between SHS and HDL-C. WMD—weighted mean difference; SMD—standard mean difference.

\subsection{SHS and Risk of Abdominal Obesity}

The association between SHS and the risk of abdominal obesity was analyzed. BMI and WC were used as indexes for evaluating lipid metabolism.

Eleven studies were included in the assessment of BMI, and they showed that SHS may be associated with a higher BMI (WMD $=0.58 \mathrm{~kg} / \mathrm{m}^{2}, 95 \% \mathrm{CI}: 0.34$ to $0.81 \mathrm{~kg} / \mathrm{m}^{2}, \mathrm{I}^{2}=67.3 \%$, Figure $4 \mathrm{~A}$ ). In the subgroup analysis, data were divided into four groups: children (1-10 years), teenagers (10-18 years), adults (26-50 years), and elderly (50-74 years). SHS showed different degrees of impact on the four groups. In the adults group, there was a stronger association between SHS and BMI $\left(\mathrm{WMD}=1.31 \mathrm{~kg} / \mathrm{m}^{2}, 95 \% \mathrm{CI}: 0.52\right.$ to $2.11 \mathrm{~kg} / \mathrm{m}^{2}, \mathrm{I}^{2}=38.6 \%$, Figure $\left.4 \mathrm{~A}\right)$ than in the children group $\left(\mathrm{WMD}=0.47 \mathrm{~kg} / \mathrm{m}^{2}, 95 \% \mathrm{CI}: 0.15\right.$ to $0.78 \mathrm{~kg} / \mathrm{m}^{2}, \mathrm{I}^{2}=77.5 \%, p<0.05$, Figure $4 \mathrm{~A}$ ), and it showed stronger trends than in the teenagers group (WMD $=0.54 \mathrm{~kg} / \mathrm{m}^{2}, 95 \%$ CI: 0.03 to $1.05 \mathrm{~kg} / \mathrm{m}^{2}, \mathrm{I}^{2}=54.0 \%$, $0.05<p<0.10$, Figure 4A). No significant effects were shown in the elderly group. 


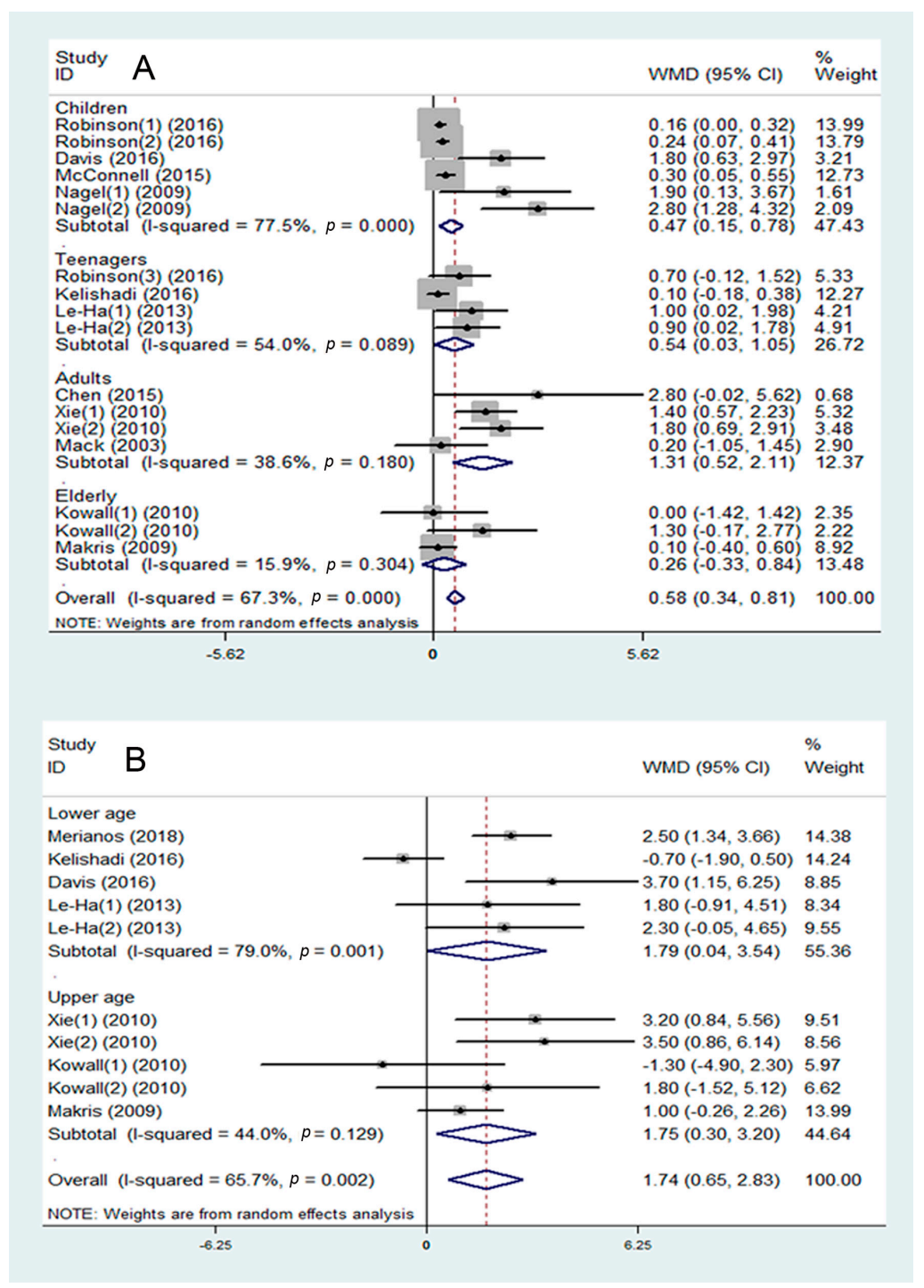

Figure 4. Meta-analysis of secondhand smoke (SHS) and risk of abdominal obesity: (A) association between SHS and body mass index (BMI); (B) association between SHS and waist circumference (WC). WMD—weighted mean difference; SMD—standard mean difference.

Seven studies were included in the assessment of the association between SHS and WC. It was found that SHS may be associated with a higher WC (WMD $=1.74 \mathrm{~cm}, 95 \%$ CI: 0.65 to $2.83 \mathrm{~cm}$, $\mathrm{I}^{2}=65.7 \%$, Figure $\left.4 \mathrm{~B}\right)$. All studies were divided into two subgroups: lower age group (7-19 years) and upper age group (30-74 years). In the subgroup analysis, SHS was positively associated with WC in both the lower age group (WMD $=1.79 \mathrm{~cm}, 95 \% \mathrm{CI}$ : 0.04 to $3.54 \mathrm{~cm}, \mathrm{I}^{2}=79.0 \%$, Figure $4 \mathrm{~B}$ ) and the upper age group (WMD $=1.75 \mathrm{~cm}, 95 \%$ CI: 0.30 to $3.20 \mathrm{~cm}, \mathrm{I}^{2}=44.0 \%$, Figure $4 \mathrm{~B}$ ).

\section{Discussion}

Metabolic syndrome is a combination of metabolic abnormalities. Kaur et al. reported that the global prevalence of metabolic syndrome ranges from $10 \%$ to as much as $84 \%$, depending on the ethnicity, age, gender, and race of individuals in the population [37]. Patients with metabolic syndrome are at high risk for developing diabetes, cardiovascular disease, and a plethora of cancers, and they have an increased rate of mortality [38-40]. The main features of the metabolic syndrome include glucose and lipid metabolism disorders, insulin resistance, and abdominal obesity. In terms of glucose metabolism, levels of FPG and insulin are often used as indicators. Our study found that SHS may 
be positively associated with FPG in the upper age group. The levels of insulin were also positively associated with SHS exposure. Thus, it can be speculated that adults may be more sensitive than minors in terms of the effects of SHS on glucose metabolic disorder. In terms of lipid metabolism, lipid (total cholesterol, triglycerides, HDL-C, LDL-C) levels are usually analyzed. Our study found that SHS was positively associated with the level of LDL-C and negatively associated with the level of HDL-C in the lower age group. Therefore, it can be speculated that the risk of dyslipidemia caused by SHS is higher among younger people than among the older ones. According to our meta-analysis, SHS has a positive impact on BMI. In different age groups, SHS showed the highest degree of impact on BMI values of people aged 26 to 50 years. However, BMI cannot represent abdominal obesity completely, as it gives no indication of distribution of body fat. WC is a highly sensitive and specific measure of abdominal fat accumulation and thus it is valuable for identifying individuals with abdominal obesity who are at risk of developing metabolic complications [41]. Our study also found that SHS was positively associated with WC. Therefore, it is suggested that exposure to SHS is associated with an increased risk of developing abdominal obesity. In summary, we suggest that SHS may be closely related to the development of metabolic syndrome.

Next, we will try to further explain the age difference that exists in our results. In our study, the level of FPG was increased in older people but showed no effect in younger people. The balance between insulin secretion from $\beta$-cells and peripheral insulin sensitivity is what maintains normal glucose homeostasis [42]. It is reported that the ability to regulate glucose is progressively lost with age [43]. The actions of insulin and $\beta$-cell function also decrease with age [44,45]. Therefore, SHS may more easily destroy glucose homeostasis in older people and aggravate the age-related disorder of glucose metabolism. In younger people, the body's glucose metabolism follows a normal process-insulin secretion from $\beta$-cells is tightly coupled to the availability of glucose, allowing glucose to be maintained within a stable and normal range [42]. When young people are exposed to SHS, the influence may be dynamically regulated by homeostasis mechanisms of their bodies.

In our meta-analysis, the positive association between SHS and levels of LDL-C, and the negative association between SHS and HDL-C were more obvious in younger people than in older people. According to Murakata et al.'s study, the serum concentration of LDL-C is positively correlated with age, and HDL-C is negatively correlated with age [46]. These changes that occur with increasing age are consistent with the trends of blood lipids caused by SHS in our hypothesis. Therefore, it can be speculated that the effects of SHS on blood lipids in older people might be covered by age-related effects. In addition, children and teenagers are at a critical stage of growth and development, and their blood lipids are susceptible to living environmental factors, such as unhealthy diets, smoking, pesticides, and metals $[19,47,48]$. This may explain why SHS is more likely to lead to significant dyslipidemia in younger people than in older people.

Our study focused on a very timely public health topic-metabolic disorder. It is the first study to use a meta-analysis to review the potential association of SHS with metabolic syndrome and to explain the possible age differences. The included studies are up-to-date and of sufficient quality. Abundant indicators to evaluate metabolic syndrome were used in our study. Our study still needs some improvements-more databases should be included in our study and more subgroups could be analyzed.

\section{Conclusions}

In conclusion, the association of metabolic syndrome with SHS varies with age. When exposed to SHS, older people may be more susceptible to glucose metabolic disorder, but younger people may be more susceptible to lipid metabolic disorder.

Author Contributions: Conceptualization: H.-J.C. and Y.-E.Y.; Data curation: H.-J.C.; Formal analysis: H.-J.C., G.-L.L., and D.-S.P.; Investigation: H.-J.C., G.-L.L., and A.S.; Methodology: H.-J.C., G.-L.L., and D.-S.P.; Project administration: Y.-E.Y.; Software: A.S.; Supervision: Y.-E.Y.; Validation: G.-L.L., D.-S.P., and W.-X.Z.; Visualization: A.S.; Writing—original draft: H.-J.C.; Writing—review and editing: A.S., W.-X.Z., and Y.-E.Y. 
Funding: This research was funded by the National Natural Science Foundation of China, grant numbers 81570792 and 81270950 .

Conflicts of Interest: The authors declare no conflict of interest.

\section{References}

1. Oberg, M.; Jaakkola, M.S.; Woodward, A.; Peruga, A.; Pruss-Ustun, A. Worldwide burden of disease from exposure to second-hand smoke: A retrospective analysis of data from 192 countries. Lancet 2011, 377, 139-146. [CrossRef]

2. Law, M.R.; Morris, J.K.; Wald, N.J. Environmental tobacco smoke exposure and ischaemic heart disease: An evaluation of the evidence. BMJ 1997, 315, 973-980. [CrossRef] [PubMed]

3. Hollenbach, J.P.; Schifano, E.D.; Hammel, C.; Cloutier, M.M. Exposure to secondhand smoke and asthma severity among children in Connecticut. PLoS ONE 2017, 12, e0174541. [CrossRef] [PubMed]

4. Hackshaw, A.K.; Law, M.R.; Wald, N.J. The accumulated evidence on lung cancer and environmental tobacco smoke. BMJ 1997, 315, 980-988. [CrossRef] [PubMed]

5. Barnoya, J.; Glantz, S.A. Cardiovascular effects of secondhand smoke: Nearly as large as smoking. Circulation 2005, 111, 2684-2698. [CrossRef] [PubMed]

6. Kim, D.; Choy, Y.S.; Park, E.C. Association between secondhand smoke and glycemic control in adult diabetes patients. Prev. Med. 2017, 94, 48-54. [CrossRef] [PubMed]

7. Oba, S.; Suzuki, E.; Yamamoto, M.; Horikawa, Y.; Nagata, C.; Takeda, J.; The Gifu Diabetes Study Group. Active and passive exposure to tobacco smoke in relation to insulin sensitivity and pancreatic beta-cell function in Japanese subjects. Diabetes Metab. 2015, 41, 160-167. [CrossRef]

8. Aguilar, M.; Bhuket, T.; Torres, S.; Liu, B.; Wong, R.J. Prevalence of the metabolic syndrome in the United States, 2003-2012. JAMA 2015, 313, 1973-1974. [CrossRef] [PubMed]

9. Ford, E.S.; Li, C.; Zhao, G.; Pearson, W.S.; Mokdad, A.H. Prevalence of the metabolic syndrome among U.S. adolescents using the definition from the International Diabetes Federation. Diabetes care 2008, 31, 587-589. [CrossRef] [PubMed]

10. Sherling, D.H.; Perumareddi, P.; Hennekens, C.H. Metabolic Syndrome. J. Cardiovasc. Pharmacol. Ther. 2017, 22, 365-367. [CrossRef]

11. Hanson, R.L.; Imperatore, G.; Bennett, P.H.; Knowler, W.C. Components of the "metabolic syndrome" and incidence of type 2 diabetes. Diabetes 2002, 51, 3120-3127. [CrossRef]

12. Roopchand, D.E.; Carmody, R.N.; Kuhn, P.; Moskal, K.; Rojas-Silva, P.; Turnbaugh, P.J.; Raskin, I. Dietary Polyphenols Promote Growth of the Gut Bacterium Akkermansia muciniphila and Attenuate High-Fat Diet-Induced Metabolic Syndrome. Diabetes 2015, 64, 2847-2858. [CrossRef]

13. Kim, J.Y.; Yadav, D.; Ahn, S.V.; Koh, S.B.; Park, J.T.; Yoon, J.; Yoo, B.S.; Lee, S.H. A prospective study of total sleep duration and incident metabolic syndrome: The ARIRANG study. Sleep Med. 2015, 16, 1511-1515. [CrossRef]

14. Wennberg, M.; Gustafsson, P.E.; Wennberg, P.; Hammarstrom, A. Irregular eating of meals in adolescence and the metabolic syndrome in adulthood: Results from a 27-year prospective cohort. Public Health Nutr. 2016, 19, 667-673. [CrossRef]

15. Booth, F.W.; Roberts, C.K.; Laye, M.J. Lack of exercise is a major cause of chronic diseases. Compr. Physiol. 2012, 2, 1143-1211. [CrossRef]

16. Hu, J.; Dong, Y.; Chen, X.; Liu, Y.; Ma, D.; Liu, X.; Zheng, R.; Mao, X.; Chen, T.; He, W. Prevalence of suicide attempts among Chinese adolescents: A meta-analysis of cross-sectional studies. Compr. Psychiatry 2015, 61, 78-89. [CrossRef]

17. Zhong, G.C.; Liu, Y.; Chen, N.; Hao, F.B.; Wang, K.; Cheng, J.H.; Gong, J.P.; Ding, X. Reproductive factors, menopausal hormone therapies and primary liver cancer risk: A systematic review and dose-response meta-analysis of observational studies. Hum. Reprod. Update 2016, 23, 126-138. [CrossRef]

18. Higgins, J.P.; Thompson, S.G.; Deeks, J.J.; Altman, D.G. Measuring inconsistency in meta-analyses. BMJ 2003, 327, 557-560. [CrossRef] [PubMed]

19. Merianos, A.L.; Jandarov, R.A.; Khoury, J.C.; Mahabee-Gittens, E.M. Tobacco Smoke Exposure Association with Lipid Profiles and Adiposity Among U.S. Adolescents. J. Adolesc. Health 2018, 62, 463-470. [CrossRef] [PubMed] 
20. Kim, S.; Kang, S.H.; Han, D.; Kim, S.H.; Kim, H.J.; Park, J.J.; Cho, Y.; Yoon, Y.E.; Han, K.D.; Oh, I.Y.; et al. Relation between secondhand smoke exposure and cardiovascular risk factors in never smokers. J. Hypertens. 2017, 35, 1976-1982. [CrossRef] [PubMed]

21. Robinson, O.; Martinez, D.; Aurrekoetxea, J.J.; Estarlich, M.; Somoano, A.F.; Iniguez, C.; Santa-Marina, L.; Tardon, A.; Torrent, M.; Sunyer, J.; et al. The association between passive and active tobacco smoke exposure and child weight status among Spanish children. Obesity 2016, 24, 1767-1777. [CrossRef]

22. Kelishadi, R.; Noori, A.; Qorbani, M.; Rahimzadeh, S.; Djalalinia, S.; Shafiee, G.; Motlagh, M.E.; Ardalan, G.; Ansari, H.; Asayesh, H.; et al. Are active and passive smoking associated with cardiometabolic risk factors in adolescents? The CASPIAN-III Study. Paediatr. Int. Child. Health 2016, 36, 181-188. [CrossRef]

23. Davis, C.L.; Tingen, M.S.; Jia, J.; Sherman, F.; Williams, C.F.; Bhavsar, K.; Wood, N.; Kobleur, J.; Waller, J.L. Passive Smoke Exposure and Its Effects on Cognition, Sleep, and Health Outcomes in Overweight and Obese Children. Child. Obes. 2016, 12, 119-125. [CrossRef]

24. McConnell, R.; Shen, E.; Gilliland, F.D.; Jerrett, M.; Wolch, J.; Chang, C.C.; Lurmann, F.; Berhane, K. A longitudinal cohort study of body mass index and childhood exposure to secondhand tobacco smoke and air pollution: The Southern California Children's Health Study. Environ. Health Perspect. 2015, 123, 360-366. [CrossRef]

25. Chen, W.; Yun, M.; Fernandez, C.; Li, S.; Sun, D.; Lai, C.C.; Hua, Y.; Wang, F.; Zhang, T.; Srinivasan, S.R.; et al. Secondhand smoke exposure is associated with increased carotid artery intima-media thickness: The Bogalusa Heart Study. Atherosclerosis 2015, 240, 374-379. [CrossRef] [PubMed]

26. Le-Ha, C.; Beilin, L.J.; Burrows, S.; Huang, R.C.; Oddy, W.H.; Hands, B.; Mori, T.A. Gender difference in the relationship between passive smoking exposure and HDL-cholesterol levels in late adolescence. J. Clin. Endocrinol. Metab. 2013, 98, 2126-2135. [CrossRef]

27. Yang, B.; Li, M.; Chen, B.; Xu, Y.; Li, T.D. Deterioration of endothelial function and carotid intima-media thickness in Tibetan male adolescents exposed to second-hand smoke. J. Renin Angiotensin Aldosterone Syst. 2012, 13, 413-419. [CrossRef] [PubMed]

28. Dulger, H.; Donder, A.; Sekeroglu, M.R.; Erkoc, R.; Ozbay, B. Investigation of the relationship between serum levels of cotinine and the renal function in active and passive smokers. Ren. Fail. 2011, 33, 475-479. [CrossRef] [PubMed]

29. Xie, B.; Palmer, P.H.; Pang, Z.; Sun, P.; Duan, H.; Johnson, C.A. Environmental tobacco use and indicators of metabolic syndrome in Chinese adults. Nicotine Tob. Res. 2010, 12, 198-206. [CrossRef]

30. Moss, D.R.; Lucht, L.A.; Kip, K.E.; Reis, S.E. Acute physiologic effects of secondhand smoke exposure in children. Nicotine Tob. Res. 2010, 12, 708-714. [CrossRef] [PubMed]

31. Kowall, B.; Rathmann, W.; Strassburger, K.; Heier, M.; Holle, R.; Thorand, B.; Giani, G.; Peters, A.; Meisinger, C. Association of passive and active smoking with incident type 2 diabetes mellitus in the elderly population: The KORA S4/F4 cohort study. Eur. J. Epidemiol. 2010, 25, 393-402. [CrossRef] [PubMed]

32. Nagel, G.; Arnold, F.J.; Wilhelm, M.; Link, B.; Zoellner, I.; Koenig, W. Environmental tobacco smoke and cardiometabolic risk in young children: Results from a survey in south-west Germany. Eur. Heart J. 2009, 30, 1885-1893. [CrossRef] [PubMed]

33. Makris, T.K.; Thomopoulos, C.; Papadopoulos, D.P.; Bratsas, A.; Papazachou, O.; Massias, S.; Michalopoulou, E.; Tsioufis, C.; Stefanadis, C. Association of passive smoking with masked hypertension in clinically normotensive nonsmokers. Am. J. Hypertens. 2009, 22, 853-859. [CrossRef]

34. Houston, T.K.; Person, S.D.; Pletcher, M.J.; Liu, K.; Iribarren, C.; Kiefe, C.I. Active and passive smoking and development of glucose intolerance among young adults in a prospective cohort: CARDIA study. BMJ 2006, 332, 1064-1069. [CrossRef]

35. Mack, W.J.; Islam, T.; Lee, Z.; Selzer, R.H.; Hodis, H.N. Environmental tobacco smoke and carotid arterial stiffness. Prev. Med. 2003, 37, 148-154. [CrossRef]

36. Henkin, L.; Zaccaro, D.; Haffner, S.; Karter, A.; Rewers, M.; Sholinsky, P.; Wagenknecht, L. Cigarette smoking, environmental tobacco smoke exposure and insulin sensitivity: The Insulin Resistance Atherosclerosis Study. Ann. Epidemiol. 1999, 9, 290-296. [CrossRef]

37. Kaur, J. A comprehensive review on metabolic syndrome. Cardiol. Res. Pract. 2014, 2014, 943162. [CrossRef]

38. Gami, A.S.; Witt, B.J.; Howard, D.E.; Erwin, P.J.; Gami, L.A.; Somers, V.K.; Montori, V.M. Metabolic syndrome and risk of incident cardiovascular events and death: A systematic review and meta-analysis of longitudinal studies. J. Am. Coll. Cardiol. 2007, 49, 403-414. [CrossRef] 
39. Li, C.; Hsieh, M.C.; Chang, S.J. Metabolic syndrome, diabetes, and hyperuricemia. Curr. Opin. Rheumatol. 2013, 25, 210-216. [CrossRef]

40. O'Neill, S.; O'Driscoll, L. Metabolic syndrome: A closer look at the growing epidemic and its associated pathologies. Obes. Rev. 2015, 16, 1-12. [CrossRef]

41. Bacopoulou, F.; Efthymiou, V.; Landis, G.; Rentoumis, A.; Chrousos, G.P. Waist circumference, waist-to-hip ratio and waist-to-height ratio reference percentiles for abdominal obesity among Greek adolescents. BMC Pediatr. 2015, 15, 50. [CrossRef] [PubMed]

42. Chia, C.W.; Egan, J.M.; Ferrucci, L. Age-Related Changes in Glucose Metabolism, Hyperglycemia, and Cardiovascular Risk. Circ. Res. 2018, 123, 886-904. [CrossRef] [PubMed]

43. Andres, R. Aging and diabetes. Med. Clin. N. Am. 1971, 55, 835-846. [CrossRef]

44. Defronzo, R.A. Glucose intolerance and aging: Evidence for tissue insensitivity to insulin. Diabetes 1979, 28, 1095-1101. [CrossRef] [PubMed]

45. Crockford, P.M.; Harbeck, R.J.; Williams, R.H. Influence of age on intravenous glucose tolerance and serum immunoreactive insulin. Lancet 1966, 1, 465-467. [CrossRef]

46. Murakata, Y.; Fujimaki, T.; Yamada, Y. Age-related changes in clinical parameters and their associations with common complex diseases. Biomed. Rep. 2015, 3, 767-777. [CrossRef]

47. Hedley, A.A.; Ogden, C.L.; Johnson, C.L.; Carroll, M.D.; Curtin, L.R.; Flegal, K.M. Prevalence of overweight and obesity among US children, adolescents, and adults, 1999-2002. JAMA 2004, 291, 2847-2850. [CrossRef]

48. Nascimento, S.; Goethel, G.; Gauer, B.; Sauer, E.; Nardi, J.; Cestonaro, L.; Correia, D.; Peruzzi, C.; Mota, L.; Machry, R.V.; et al. Exposure to environment chemicals and its possible role in endocrine disruption of children from a rural area. Environ. Res. 2018, 167, 488-498. [CrossRef] [PubMed]

(C) 2019 by the authors. Licensee MDPI, Basel, Switzerland. This article is an open access article distributed under the terms and conditions of the Creative Commons Attribution (CC BY) license (http://creativecommons.org/licenses/by/4.0/). 